GEOLOGICA BALCANICA 50 (2), Sofia, August 2021, pp. 69-74.

\title{
First record of an erymid lobster (Crustacea, Decapoda) from the upper Bajocian of Northwest Bulgaria
}

\author{
Lubomir Metodiev1, Docho Dochev², Svetlozar Seferinov², Silviya Petrova ${ }^{1}$ \\ ${ }^{1}$ Geological Institute, Bulgarian Academy of Sciences, Acad. G. Bonchev Str., Bl. 24, 1113 Sofia, Bulgaria; \\ e-mails: lubo@geology.bas.bg; silviya_p@geology.bas.bg \\ ${ }^{2}$ Department of Geology, Palaeontology and Fossil Fuels, Faculty of Geology and Geography, Sofia University \\ “St Kliment Ohridski”, 15 Tsar Osvoboditel Blvd,1504 Sofia, Bulgaria; emails: dochev@gea.uni-sofia.bg, \\ seferinov@gea.uni-sofia.bg
}

(Received: 30 July 2021; accepted in revised form: 31 August 2021)

\begin{abstract}
Fossil chela of an erymid lobster from a single locality of the upper Bajocian in the Western ForeBalkan Mts (NW Bulgaria) was studied. Two segments of the thoracic appendages, probably belonging to one individual, were described: 1) P1 propodus with partially preserved pollex and dactylus; and 2) P1 carpus and P1 merus attached. These elements of the first pair of pereiopods of a lobster were identified as Eryma compressum (Eudes-Deslongchamps, 1842). Eryma compressum is a well-known taxon from numerous Jurassic localities in Europe but has not been recorded in Bulgaria to date. Therefore, albeit being an isolated finding with only a few elements, the Bulgarian example contributes to the overall record of European erymid faunas from the Middle Jurassic, and especially in Eastern Europe, from where only a few erymids have been reported.
\end{abstract}

Metodiev, L., Dochev, D., Seferinov, S., Petrova, S. 2021. First record of an erymid lobster (Crustacea, Decapoda) from the upper Bajocian of Northwest Bulgaria. Geologica Balcanica 50 (2), 69-74.

Keywords: Jurassic, upper Bajocian, erymid lobster, Eryma, Crustacea, Bulgaria.

\section{INTRODUCTION}

The intensive collections of fossils from the Middle Jurassic strata in Northwest Bulgaria in the 1960s, and especially those in the area of Belogradchik along the strip of outcrops between Varbovo and Dolni Lom Villages (Vidin-Montana Districts), have provided numerous localities containing abundant and well-preserved fossils. These include a number of ammonites and brachiopods, many of which have been studied and published in the valuable papers of July Stephanov and Platon Tchou- matchenco (e.g., Stephanov, 1966, 1972; Tchoumatchenco, 1977a, b, 1978, 1993). Regrettably, the premature death of Stephanov, who had a particular interest and diligence in studying the fossils of this area, left much of his material only labeled. At the revision of Stephanov's collection, we have recently found remains of an erymid lobster, simply labeled as "Erymastacus sp., Bajocian, Prauzhda Village, Vidin District". The latter consist of a P1 propodus and attached P1 carpus and P1 merus, which are preserved in ferruginized fine-grained calcareous sandstone. The lithology of the hostrock suggests 
that it is from the lower levels of the Polaten Formation. Based on the age definitions for the Polaten Formation in the area southeast of Belogradchik, mainly from the works of Tchoumatchenco (1977a, b, 1978), the age of the erymid lobster is presumably late Bajocian. Our field knowledge (LM) allowed the lobster locality to be fixed approximately a kilometer north of Prauzhda Village (Vidin District, Fig. $1 a, b)$. The focus herein is on the description of these fossils. We assume that they belong to one individual. They are sufficiently well preserved and bear characteristic morphological features to be identified at specific level.

\section{GEOLOGICAL SETTING}

The area of the locality that yielded the fossils for this study is situated in Northwest Bulgaria, near the Bulgarian-Serbian state border. In this region, the Jurassic rocks crop out within two (southern and northern) narrow and almost parallel strips of exposures of NW-SE trend (Fig. 1a). In a regional geological context, the southern strip takes part of a thick succession of Mesozoic rocks that is deformed in a number of fault bends associated with the Vedernik thrust fault. The latter is a prominent structure that divides the internal and external structures in the northwestern part of the Balkan Zone (sensu Dabovski et al., 2002). In a local context, along the Vedernik thrust fault in the area of Prauzhda Village, a characteristic S-shaped fault bend was formed, in which the Mesozoic rocks and the underlying older strata were dislocated both vertically and laterally (Fig. 1b). Stratigraphically, the Jurassic rocks of this area lie upon varied Paleozoic rocks, but also on the red clastics of the Lower Triassic, in which the Belogradchik rocks were formed.

The rocks of the Riksa Formation take up the basal part of the Jurassic succession in the Prauzhda vicinity and the adjacent area (see Fig. 2). These sediments correspond to siliciclastic coal-bearing (lacustrine-palustrine) deposits and are ToarcianAalenian in age (Sapunov et al., 1990). Up-section, thick shallow-marine quartzose (oligomict) clastic rocks, referred to the Kichera Formation, lie with a more or less sharp lithological boundary upon the continental strata. These sediments correspond to syntransgressive deposits and are Aalenian-early Bajocian in age (Sapunov et al., 1988). From above, the Kichera Formation is covered by the shallow bioclastic terrigenous-carbonate rocks of the Polaten Formation, which are late Bajocian in age (Tchoumatchenco, 1977a, b, 1978). The latter
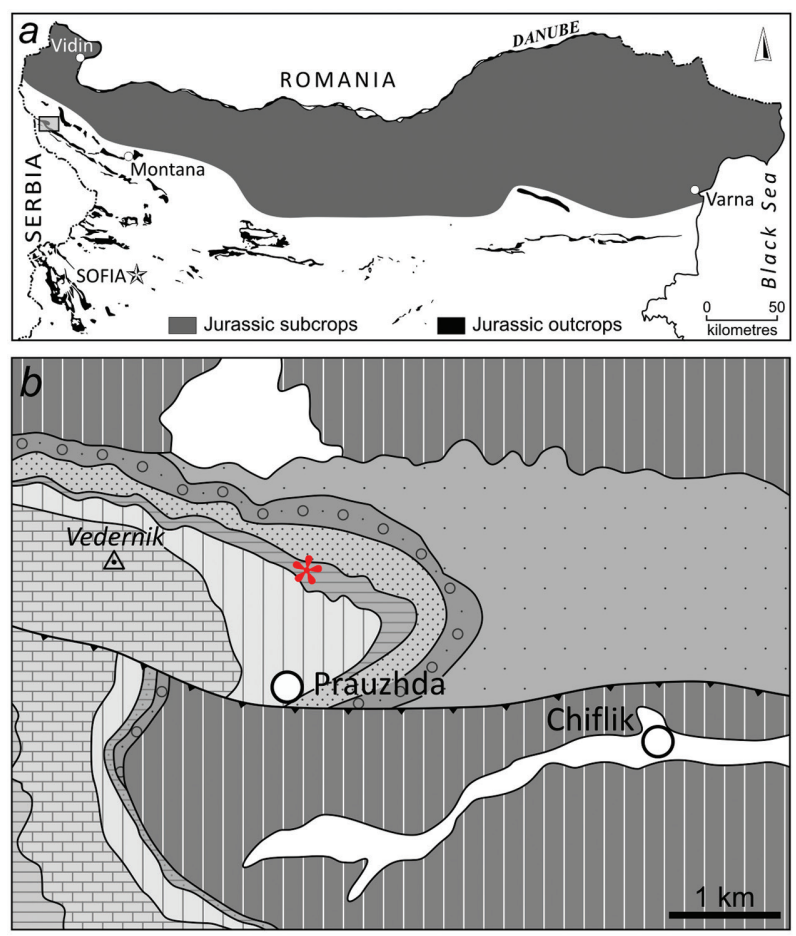

$\square$ Quaternary $\square$ Vedernik thrust fault $\square$ Lower Triassic $\square$ Paleozoic Salash Formation (Berriasian-Barremian)

West Balkan Carbonate Group (Callovian-Berriasian)

$\square$ Bov Formation (Bathonian-Callovian) $\square$ Polaten Formation (Bajocian, pars.) Kichera-Polaten Formation (Aalenian-Bathonian, pars.)

$\therefore$ Kichera Formation (Aalenian-Bajocian) 0 Riksa Formation (Toarcian-Aalenian)

Fig. 1. Location maps of the locality yielding the fossil chela for this study: a) Outcrops and subcrops of the Jurassic rocks in Bulgaria (after Sapunov and Metodiev, 2007), showing the position of the area containing the locality of Prauzhda; $b$ ) geological sketch map of the Western Fore-Balkan Mts in the area of Prauzhda Village (after Angelov et al., 2006; simplified) and the approximate position of the Prauzhda locality (red asterisk).

display sharp erosional bounding limits and, from a depositional viewpoint, denote post-transgressive deposits. They are overlain by the marlstone-limestone succession of the Bov Formation. A few unpublished ammonites (e.g., Procerites ex gr. imitator (Buckman), Polyplectites spp.) from Stephanov's collection, from scattered nearby localities, dated the basal beds of the Bov Formation as middle Bathonian. The uppermost parts of the Jurassic succession in the Prauzhda area are made up of sediments of the West Balkan Carbonate Group which have a total chronostratigraphical range from the Callovian to the Berriasian (Sapunov et al., 1988). In terms of the overall depositional history, it should be noted that the Lower-Middle Jurassic strata correspond to a trend from a relatively slow (Aalenian-Bajocian) increase to an apparently rapid (Bathonian) rise of the sea level and its composing 


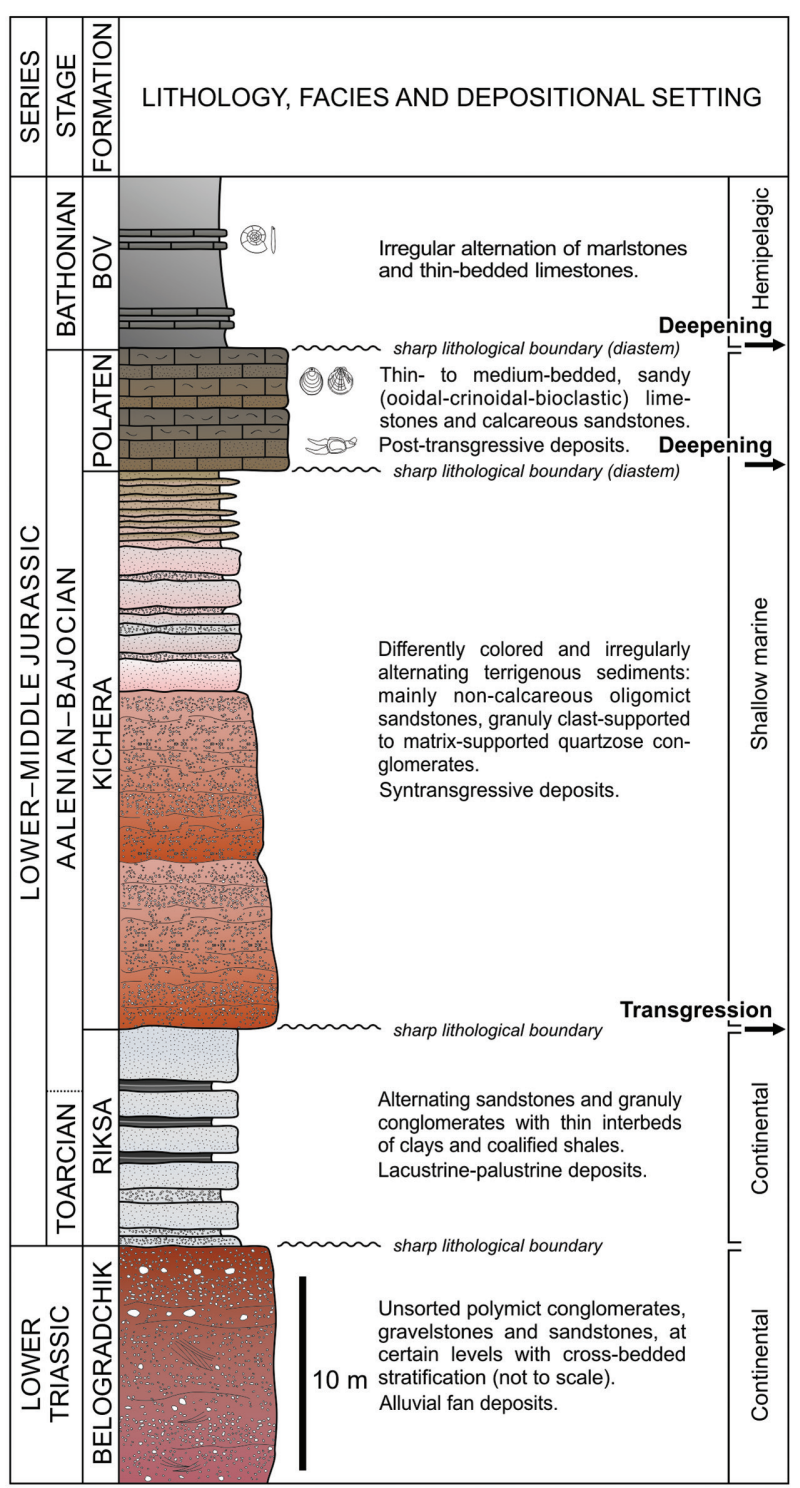

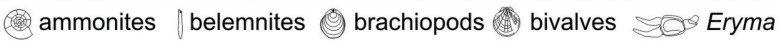

Fig. 2. Generalized stratigraphic section, facies and depositional settings of the Lower-Middle Jurassic rocks in the area of Prauzhda Village.

sediments often contain intraformational gaps due to sedimentary misaccumulation (diastems or submarine washout).

As noted above, the erymid lobster remains probably originate from the lower levels of the Polaten Formation, a few-meters thick, thin- to medium-bedded, light brown fine-grained calcareous sandstones, containing crinoidal bioclasts and tiny particles of bivalve and brachiopod debris. The beds are generally devoid of fossils, but may contain sporadic specimens, or quite rare clusters, of poorly preserved bivalves of Entolium Meek, 1865 and Oxytoma Meek, 1864, and brachiopods Sphaero- idothyris Buckman, 1917 (LM). Ammonites are virtually absent.

\section{SYSTEMATIC PART}

The terminology and taxonomic views adopted herein mainly follow Devillez and Charbonnier (2017, 2019, 2021) and Devillez et al. (2019). The described erymid lobster chela is kept at the $\mathrm{Mu}-$ seum of Palaeontology and Historical Geology at Sofia University “St Kliment Ohridski”, Bulgaria.

\section{Order Decapoda Latreille, 1802 \\ Superfamily Erymoidea Van Straelen, 1925 Family Erymidae Van Straelen, 1925 Genus Eryma Meyer, 1840}

Type species. Macrourites modestiformis Schlotheim, 1822 (p. 160, pl. 77, fig. 9), by subsequent designation (Glaessner, 1929, p. 150).

Diagnosis. According to the emended diagnosis of Devillez and Charbonnier (2019), this genus possesses thoracic appendages with chelate P1-P3. The P1 chelae display homogeneous ornament, without prominent spines. The $\mathrm{P} 1$ propodus is dorsoventrally compressed and has narrow inner and outer margins with a narrow dactylar bulge. The P1 fingers are of equal length; they are usually longer than the propodus and progressively taper to their distal edge. The pollex is wider than the dactylus. P1 chelae can be of two types: 1) with a short rectangular propodus and straight fingers, which are slightly longer than the propodus; and 2) with an elongated, subrectangular to trapezoidal propodus and curved inward fingers, which are quite longer than the propodus.

Remarks. The most extensive recent discussions of Eryma are those of Hyžný et al. (2015), and Devillez and Charbonnier (2017, 2019, 2021). Following these authors, the chelae of Eryma can easily be distinguished based on the shape of the propodus, its characteristic dorsoventral flattening and narrow margins, and the style of ornamentation, which is devoid of spines but is dense, fine and tuberculate.

Occurrence. Sinemurian-Albian: Europe (France, Germany, Italy, UK, Switzerland, Russia, Romania and Bulgaria), North Africa (Morocco), Iran, Lebanon, Madagascar, Japan, and the United States.

\section{Eryma compressum (Eudes-Deslongchamps, 1842)}

(Fig. 3a-h; Fig. 4)

1842. Palinurus compressus Eudes-Deslongchamps, p. 60, pl. 4, Figs 8-9 (carapace). 
1865. Bolina etalloni Ferry, p. 368, Pl. 7, Figs 1, 2 (left chela). 2019 Eryma compressum (Eudes-Deslongchamps): Devillez and Charbonnier, pp. 9-12 (cum syn.).

Holotype. The original material of Eudes-Deslongchamps (1842, p. 60, pl. 4, figs 8, 9), NHMUK In.22917, is a carapace from the Bathonian at Ranville, Lower Normandy, Department of Calvados (NW France). It is housed at the Natural History Museum, London (UK). The holotype was refigured by Devillez and Charbonnier (2019, fig. 5A).

Other type material. The original of Ferry (1865, p. 368, pl. 7, figs 1-2), MNHN.F.A29729, is a left chela from the Bajocian at Solutré, BourgogneFranche-Comté, Department of Saône-et-Loire (SE France). It is housed at the Natural History Museum, Paris (France). This type was refigured by Devillez and Charbonnier (2019, fig. 5E).

Synonymy. For other type materials, corresponding to synonyms of Eryma compressum (Eudes-Deslongchamps), see Devillez and Charbonnier (2019, pp. 9-12, cum syn.).

Material. Specimen Inv.-Nr U.S., J ${ }^{\text {nov }} 266$ (Fig. 3a$c, g$ ) corresponding to a P1 propodus and specimen Inv.-Nr U.S., Jnov 267 (Fig. 3d-f, h) consisting of a P1 carpus and a P1 merus. Unpublished material of July Stephanov, probably from the base of the Polaten Formation, near Prauzhda Village (Vidin District). Upper Bajocian.

Description and discussion. Medium-sized, wide and subtrapezoidal P1 propodus, which is compressed dorsoventrally (see Fig. $3 a-c$ ). The inner margin is $22 \mathrm{~mm}$ long, and the outer margin is 24.5 $\mathrm{mm}$. The thickness of the propodus is $9.5 \mathrm{~mm}$. The ventral side is slightly convex, almost flat. The dorsal side bears a pronounced mid-side longitudinal bulge. Both the inner and the outer margin are narrow and tapered. The proximal end is elliptical, with a length of $17 \mathrm{~mm}$ and a narrow collar around it. The distal end is slightly flattened, with a length of $23 \mathrm{~mm}$. It bears the very base of both the dactylus and the pollex. The latter are limited by wide and shallow grooves. The fingers are not preserved.

The P1 carpus has a rounded subtriangular outline and an elliptical cross-section, which is slightly sharpened towards both the inner and outer margin (see Fig. $3 d-f$ ). It is $14 \mathrm{~mm}$ long, $11.5 \mathrm{~mm}$ wide at its widest end, and $8.5 \mathrm{~mm}$ thick. The connections with the propodus and the merus, which are convex and elliptical, are clearly visible. The $\mathrm{P} 1$ merus is partly preserved, with a triangular shape in cross section.

The propodus, carpus and merus are ornamented with fine and dense tubercles that are accentu-

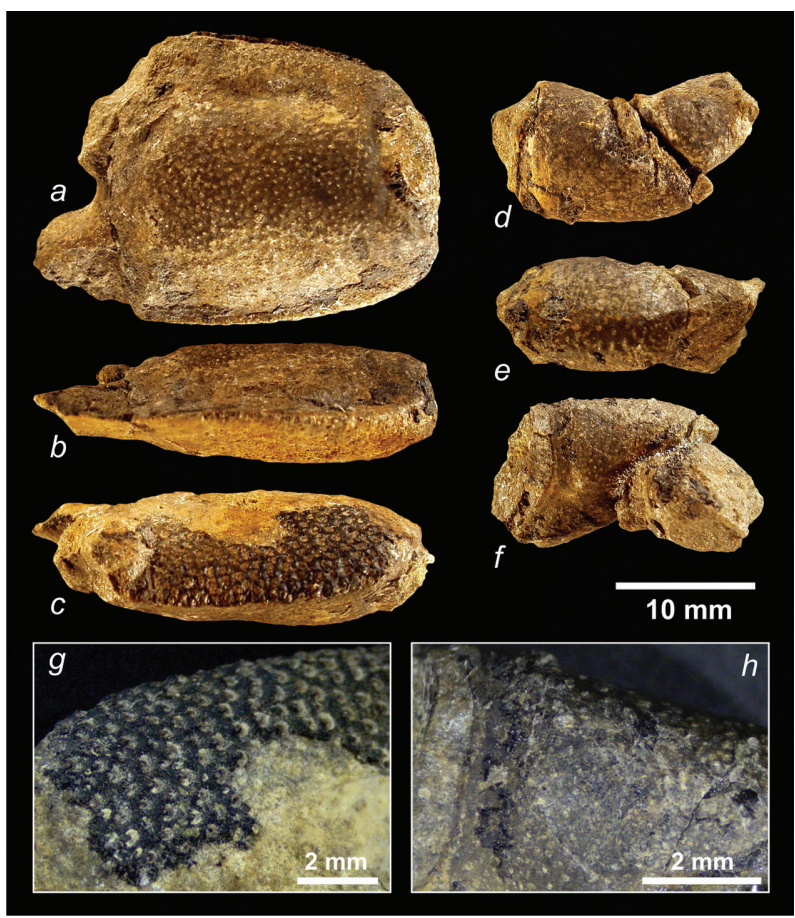

Fig. 3. Eryma compressum (Eudes-Deslongchamps, 1842) from the upper Bajocian of the area of Prauzhda Village (Vidin District, Western Fore-Balkan Mts, NW Bulgaria): $a-c$ ) P1 propodus (Inv.-Nr U.S., J ${ }^{\text {nov }} 266$ ): $a$ ) dorsal view, $b$ ) inner margin view, $c$ ) outer margin view; $d-f$ ) P1 carpus and P1 merus (Inv.-Nr U.S., J Jov 267): $d$ ) dorsal view, e) outer margin view, $f$ ) ventral view; details of ornamentation of the propodus $(g)$ and the carpus $(h)$.

ated by minute crescent-shaped concavities (see Fig. $3 g, h)$.

Having at their disposal a plentiful collection of original European specimens, Devillez and Charbonnier (2019, pp. 9-13) made a careful revision, in which twenty species (and subspecies), previously assigned to five different genera, were placed in synonymy with Eryma compressum (Eudes-Deslongchamps, 1842). They described and discussed this species in detail, and compared it with other closely related taxa. Due to the lack of preserved carapace, the generic and species identification of the Bulgarian remains is based on comparisons with the thoracic appendages revised by Devillez and Charbonnier (2019). Hence, the available Bulgarian $\mathrm{P} 1$ propodus is very similar in morphology to the original of Ferry (1865, pl. 7, figs 1-2) from the Bajocian at Solutré (France), which is the holotype for Bolina etalloni (see Devillez and Charbonnier, 2019, fig. 5E). The Bulgarian P1 carpus and merus are morphologically very similar to the equivalent 


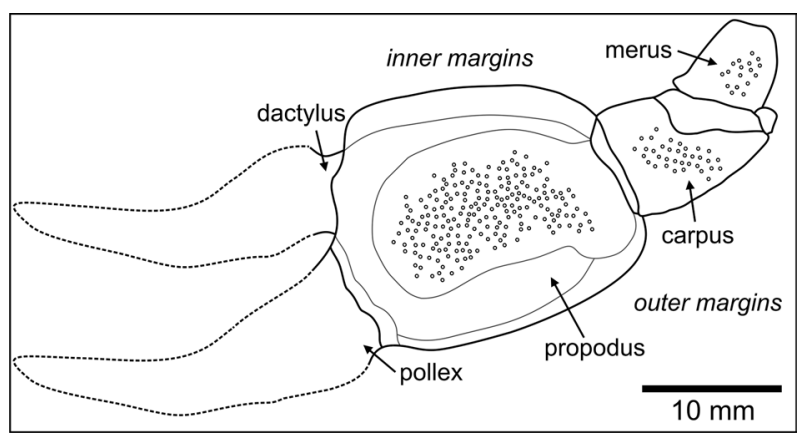

Fig. 4. Reconstruction of the chela of Eryma compressum (Eudes-Deslongchamps, 1842) from the upper Bajocian of the area of Prauzhda Village (NW Bulgaria). The fingers were restored following Devillez and Charbonnier (2019).

elements of the original specimen of Quenstedt (1858, pl. 53, figs 5-6) from the Aalenian at Aalen (Germany), which is the holotype for Glyphea aalensis (Devillez and Charbonnier, 2019, fig. 5D).

Hyžný et al. (2015) opined that Eryma Meyer, 1840 and Erymastacus Beurlen, 1928 are names that accommodate erymid lobsters, which differ sufficiently from each other, and therefore represent distinct genera. This opinion was argued and supported by abundant and well-preserved material. An emended diagnosis for Erymastacus was also made (ibid.). Following the emended diagnosis for the thoracic appendages of Eryma, however, and also in accordance with the opinion of Devillez and Charbonnier (2019), who, among others, argued that Erymastacus is a junior subjective synonym of Eryma, we refer our specimens to Eryma.

Occurrence. As stated by Devillez and Charbonnier (2019), Eryma compressum is an erymid species, which is common in the Middle Jurassic strata of Western Europe, but also occurs in Iran and Morocco. Detailed information on the stratigraphical distribution and known localities can be found in the work of Devillez and Charbonnier (2019), and nothing can be added.

\section{CONCLUDING REMARKS}

Despite being represented by single elements, the erymid lobster described herein is valuable, since it documents the presence of a fossil group that still remains poorly recorded in the Jurassic of Eastern Europe. The abundant erymid faunas from elsewhere suggest that these decapods were an important component of the fossil assemblages of the Jurassic across Europe and beyond. The scarcity of the Bulgarian material does not allow for deeper understanding and conclusions; nevertheless, it is of interest in the framework of the overall Jurassic fossil record, as it seems to be an echo of times of significant diversification of crustaceans.

\section{Acknowledgements}

The authors are grateful to Prof. Sylvain Charbonnier and Dr Julien Devillez (Muséum national d'Histoire naturelle, Centre de Recherche en Paléontologie, Sorbonne Université, Paris) for their highly constructive suggestions and comments on an earlier version of the manuscript. This work has been carried out in the framework of the National Science Program "Environmental Protection and Reduction of Risks of Adverse Events and Natural Disasters", approved by the Resolution of the Council of Ministers No. 577/17.08.2018 and supported by the Bulgarian Ministry of Education and Science (Agreement No. DO 1-363/17.12.2020).

\section{REFERENCES}

Angelov, V., Antonov., M., Gerdjikov, S., Klimov, I., Petrov, P., Kiselinov, H., Dobrev, G. 2006. Geologic map of Bulgaria in scale 1:50,000, Knyazhevats and Belogradchik map sheets. Bulgarian National Geological Survey, Sofia.

Dabovski, C., Boyanov, I., Khrischev, K., Nikolov, T., Sapunov, I., Yanev, Y., Zagorchev, I. 2002. Structure and Alpine evolution of Bulgaria. Geologica Balcanica 32 (3-4), 9-15.

Devillez, J., Charbonnier, S. 2017. The genus Eryma Meyer, 1840 (Crustacea: Decapoda: Erymidae): new synonyms, systematic and stratigraphic implications. Bulletin de la Société géologique de France 188 (15), 1-10, https://doi. org/10.1051/bsgf/2017178.
Devillez, J., Charbonnier, S. 2019. Review of the Early and Middle Jurassic erymid lobsters (Crustacea: Decapoda). Bulletin de la Société géologique de France 190 (6), 1-37, https://doi.org/10.1051/bsgf/2019005.

Devillez, J., Charbonnier, S. 2021. Review of the Late Jurassic erymid lobsters (Crustacea: Decapoda). Geodiversitas 43 (2), 25-73, https://doi.org/10.5252/geodiversitas$2021 v 43 a 2$.

Devillez, J., Charbonnier, S., Barriel, V. 2019. An attempt to clarify phylogenetic affinities of erymid lobsters (Decapoda) using morphological characters. Arthropod Systematics \& Phylogeny, Senckenberg 77 (3), 365-395, https://doi. org/10.26049/ASP77-3-2019-1. 
Eudes-Deslongchamps, E. 1842. Mémoire pour servir à l'histoire naturelle des crustacés fossiles. Mémoire de la Société linnéenne de Normandie 7, 53-60.

Ferry, H., de. 1865. Note sur les crustacés et les spongitaires de la base de l'étage bathonien des environs de Mâcon. Bulletin de la Société linnéenne de Normandie 9, 365-376, https://www.biodiversitylibrary.org/page/33929322.

Glaessner, M.F. 1929. Crustacea. Decapoda. In: Pompeckj, J.F. (Ed.), Fossilium Catalogus. I. Animalia. Pars 41. W. Junk, Berlin, 464 pp.

Hyžný, M., Schlögl, J., Charbonnier, S., Schweigert, G., Rulleau, L., Gouttenoire, M. 2015. Intraspecific variation and taphonomy of a new erymid lobster (Crustacea: Decapoda) from the Middle Jurassic of Belmont (Beaujolais, France). Geobios 48 (5), 371-384, http://dx.doi.org/10.1016/j.geobios.2015.07.006.

Latreille, P.A. 1802. Histoire naturelle, générale et particulière des crustacés et des insectes. Tome 3. Dufart, Paris, 468 pp., https://doi.org/10.5962/bhl.title.15764.

Meyer, H., von. 1840. Briefliche Mittheilungen. Neues Jahrbuch für Mineralogie, Geognosie, Geologie und Petrefactenkunde 1840, 576-587.

Quenstedt, F.A. 1856-1858. Der Jura. H. Laupp, Tübingen, 842 pp.

Schlotheim, E.F., von. 1822. Beiträge zur näheren Bestimmung der versteinerten und fossilen Krebsarten. Nachträge zur Petrefactenkunde, Becker, Gotha, 17-37.

Sapunov, I., Metodiev, L. 2007. Main features of the Jurassic in Bulgaria. Comptes rendus de l'Académie bulgare des Sciences 60 (2), 169-178.

Sapunov, I., Tchoumatchenco, P., Mitov, P. 1988. Jurassic development of North-west Bulgaria. Geologica Balcanica 18 (1), 3-82 (in Russian, with English and Russian abstracts).
Sapunov, I., Tchoumatchenco, P., Černjavska, S. 1990. Formal lithostratigraphic units for the Jurassic continental rocks in West Bulgaria. Review of the Bulgarian Geological Society 50 (1), 10-20.

Stephanov, J. 1966. The Middle Jurassic ammonite genus Oecotraustes Waagen. Travaux sur la géologie de Bulgarie, Série Paléontologie 8, 29-69.

Stephanov, J. 1972. Monograph on the Bathonian ammonite genus Siemiradzkia Hyatt, 1900 (nomenclature, taxonomy and phylogeny). Bulletin of the Geological Institute, Series Palaeontology 21, 5-82.

Tchoumatchenco, P. 1977a. Les biozones de brachiopodes du Jurassique moyen en Bulgarie. Geologica Balcanica 7 (1), 97-108.

Tchoumatchenco, P. 1977b. Sur la stratigraphie des brachiopodes du Jurassique moyen dans la région de Belogradchik. Review of the Bulgarian Geological Society 38 (3), 314319 (in Bulgarian, with French summary).

Tchoumatchenco, P. 1978. Brachiopodes du Jurassique moyen des environs du village de Dolni Lom, District de Vidin (Bulgarie du Nord-ouest). Annuaire de l'Université de Sofia, Faculté de géologie et géographie 69 (1), 193-232 (in Bulgarian, with French summary).

Tchoumatchenco, P. 1993. Brachiopod thanatocoenoses in the Aalenian, Bajocian and Bathonian of Western Bulgaria and their distribution. Palaeogeography, Palaeoclimatology, Palaeoecology 100 (1-2), 159-168, https://doi. org/10.1016/0031-0182(93)90039-L.

Van Straelen, V. 1925. Contribution à l'étude des crustacés décapodes de la période jurassique. Mémoires de la Classe des Sciences de l'Académie royale de Belgique 7 (2), 1-462. 